\title{
41 漏れ電流測定用器具と人体インピーダンスに関する考察
}

岡野 宏（東京都立工業技術センター医用電気機器研究室）

[目的]医用電気機器の安全通則（JIS T 1001 2) が1992年改正され, 規格中で漏れ電流測定用器具が変 更された. 器具は規格から判断して感電に対する人体 を模擬する等価回路である。つまり, 人体の等価回路 の值が変更されたと考觉ることができる，そこで，実 際の等価回路である人体インピーダンスを計測し, 器 具の変更の意味や相違点について考察を行った.

[方法]

(1)新（1992年改正）及び旧（1983年制定）の各器具 について, 周波数特性を計算と LCR メータの計測值 で求めた.

(2)新旧器具を用いて, 実際の医用機器の漏れ電流を 計測した。

(3)実際の人体各部位間のインピーダンスを，LCR メータを用いて計測した.

[結果]

(1)新器具は 4 端子回路網であり, 人力電圧と出力電 压の比が $20 \log _{10} \frac{v_{0}(f)}{v i(f=10)}$ の周波数特性を示すロ一 パスフィルタである。これに対し旧器具は，2端子 回路網であり, 器具のインピーダンスが, $20 \log _{10}$
$\frac{Z(f)}{Z(f=10)}$ の周波数特性をむっている.

(2)このため，医用機器の商用周波数成分の漏孔電流 值は新旧器具で同值を示すが, 例光ば,超音波洗浄器の 様に高周波成分が多いと異なった值を示す．これは， 漏れ電流の波形が器具により異なるからである.

(3)実際の人体インピーダンスは C と R の並列等価回 路で示すことができる.そこで，この等価回路を用い て,インピーダンスの大きさの絶対值 $|Z|$ と位相角 $\theta$ の周波数特性を求めた。

\section{[考察]}

(1)新器具は 4 端子ローパスフィルタであるため, 高 周波成分を適切に除去し, 旧器具に比べより理論值に 近い周波数特性を示した.

(2)このことは，実際の医用機器の漏れ電流波形にお。 いて確認できた.

(3)実際の人体インピーダンスは乾湿状態の差を除 き, 関係文献と類似の傾向を示した. 又, 新旧器具と 実際の人体インピーダンスの周波数特性は異なってい るが, 新旧器具は共に, 安全側に余裕をもった規格值 であることがわかった。

\section{2 電気機器等の異常による電源電圧の異常例}

小林 馨, 白井敦史, 田村千秋, 瓜生伸一 (北里大東病院 $\mathrm{ME}$ センター部) 川村正春 (北里大東病院事務部総務課施設係), 渡辺 敏 (北里大麻酔科)

現在の医療は電気に対する依存度が大きく，適正な 電源の供給が行われないと，医療機器および病院機能 は，その本来の機能を発揮しない。このためには電気 設備の安全性, 信頼性を維持し, 安定した定格電压の 供給が必要である.

しかしながら，院内各部門で使用している各種電気 機器の異常等で, 電源電圧の異常が起こる可能性があ
り,この時には院内全体の電源供給に影響を与える危 険性がある.

今回, 当施設内の電気機器の電源コード損傷および コンセントの誤配線が原因で, 院内全体の非常電源お よび一般電源に対地間電圧異常が発生した実例を経験 したので報告する. 